\title{
THE SITUATION OF LATINOS IN THE UNITED STATES DURING D. TRUMP'S PRESIDENCY: OVERVIEW OF POLITICAL TRANSFORMATIONS' ISSUES IN THE PUBLICATIONS OF AMERICAN AUTHORS FOR 2018-2020 ${ }^{1}$
}

\author{
Ilya A. Sokov \\ Volgograd State University, Volgograd, Russian Federation
}

\begin{abstract}
Introduction. The overview's subject is the problem of Latin Americans' situation (citizens and noncitizens of the USA) during the D. Trump's presidency, reflected in new works by American authors. The historiography overview consist of researchers' monographs from American universities and analytical articles from academic journals and periodicals. The overview's logical systematization is based on two principles: the established chronological framework and the grouping of author's views on a particular problem. Relevance. The overview topic's relevance is caused by significant reduction in the rights and increased prosecution of Latinos in the contemporary of the United States which is emphasized by the American authors themselves. The authors emphasized the theoretical basis for the new migration political process was making D. Trump's conservative nationalist policy which is called "America First". The implementation of such policy leads to new challenges in ensuring national security, exacerbating social conflicts and splitting the American society. Purpose. The work's purpose is to highlight new trends in the US immigration policy that significantly restricted the rights and freedoms of Latin American citizens and Latin American refugees living in the country during this period. Methods. The author of the article used the following methodological tools: the scientific principle of objectivity, which allowed us to assess the degree of subjective information contained in the publications; the ontological (substantive) approach, which was used to clarify the actors of conflict interaction in the process of the White House's transformational policy presented in new American studies; the institutional method based on the research works, which allowed us to determine changes in the functions and activities of the US government's departments when dealing with immigration issues and the situation of Latin American citizens and non-citizens in the United States during the D. Trump's presidency. Results. The results consist in the recognition of the nativist and conservative nationalist policy of the US government towards Latin Americans by the American academic and expert community, which contradicts the values declared by the American society and contributes to its separation and division creating greater inequality within it. Although the historiography overview did not aim to examine Latinos' situation in the United States in historical retrospect. All of these could be noted in the above works that no American author noted an improvement in the situation of Latinos during D. Trump's presidency, compared to the previous administrations of B. Clinton, G.W. Bush and B. Obama. Many authors noted that new problems have been added to the old problems of Latinos and incoming immigrants. The results $\vec{\delta}$ area. The results obtained can be used by Russian Americanist researchers to conduct their further researches in the fields of area studies, international relations, international processes, and the history of foreign countries. Conclusion. The Latinos' situation analysis in the United States during the D. Trump's presidency was based on American authors' publications for 2018-2020, which suggests not only the devastating impact of the White House's transformative policies toward Latinos, but also the changing structure of American society itself, which is inherently immigrant.
\end{abstract}


Key words: D. Trump, L. Obrador, Latinos, "Sun Belt", carceral states, discrimination, American-Mexican relations, political transformation.

Citation. Sokov I.A. The Situation of Latinos in the United States During D. Trump's Presidency: Overview of Political Transformations' Issues in the Publications of American Authors for 2018-2020. Vestnik Volgogradskogo gosudarstvennogo universiteta. Seriya 4. Istoriya. Regionovedenie. Mezhdunarodnye otnosheniya [Science Journal of Volgograd State University. History. Area Studies. International Relations], 2021, vol. 26, no. 3, pp. 249-263. (in Russian). DOI: https://doi.org/10.15688/jvolsu4.2021.3.22

УДК 24(73)“"2018/2020”2323

ББК 63.3(7Coe)64-3

Дата поступления статьи: 24.09.2020

Дата принятия статьи: 22.01.2021

\title{
ПОЛОЖЕНИЕ ЛАТИНОС В США ВО ВРЕМЯ ПРЕЗИДЕНТСТВА Д. ТРАМПА: ОБЗОР ПРОБЛЕМАТИКИ ПОЛИТИЧЕСКИХ ТРАНСФОРМАЦИЙ В ПУБЛИКАЦИЯХ АМЕРИКАНСКИХ АВТОРОВ ЗА 2018-2020 ГОДЫ ${ }^{1}$
}

\author{
Илья Анатольевич Соков \\ Волгоградский государственный университет, г. Волгоград, Российская Федерация
}

\begin{abstract}
Аннотация. Введение. Предметом обзора явилась проблематика положения латиноамериканцев (граждан и не граждан США) за время президентства Д. Трампа, отраженная в новых работах американских авторов. В историографический обзор вошли монографии исследователей американских университетов, аналитические статьи из академических и периодических журналов. Логика систематизации обзора исходит из двух принципов: установленных хронологических рамок и группировки авторских взглядов на определенную проблему. Актуальность темы обзора вызвана существенным снижением прав и усилением притеснения латиноамериканцев в современных США, что подчеркивают сами американские авторы. Особо ими выделяются новые условия миграционного процесса, теоретическим основанием которого явилось проведение администрацией президента Д. Трампа консервативной националистической политики «Америка прежде всего». Цель работы состоит в выявлении взглядов американских исследователей и экспертов на проблему положения латиноамериканцев в США в период работы администрации президента Д. Трампа. Методы. В статье использовались следующие методологические инструменты: научный принцип объективности, который позволил оценить степень субъективной информации, содержащейся в использованных публикациях; онтологический (субстанциональный) подход, который использовался для уточнения акторов конфликтного взаимодействия в процессе трансформационной политики Белого дома, представленных в новых американских исследованиях; институциональный метод, позволивший на основании исследуемых работ определить изменения функций и деятельности ведомств американского правительства при решении иммиграционных вопросов и положения латиноамериканских граждан и не граждан в США при президентстве Д. Трампа. Результа$m b l$. Заключаются в признании американским академическим и экспертным сообществом проведения нативистской и консервативной националистической политики правительством США в отношении латиноамериканцев, что противоречит декларируемым американским обществом ценностям и способствует его разобщению и разделению, созданию в нем большего неравенства. Всеми американскими авторами отмечено ухудшение положения латинос во время президентства Д. Трампа, по сравнению с прошлыми администрациями Б. Клинтона, Дж. Буша-мл. и Б. Обамы. Область применения результатов. Полученные результаты могут использоваться российскими американистами для проведения своих дальнейших исследований в области международных отношений.
\end{abstract}

Ключевые слова: Д. Трамп, Л. Обрадор, латинос, «Солнечный пояс», тюремные штаты, дискриминация, американо-мексиканские отношения, политическая трансформация.

Цитирование. Соков И. А. Положение латинос в США во время президентства Д. Трампа: обзор проблематики политических трансформаций в публикациях американских авторов за 2018-2020 годы // Вестник Волгоградского государственного университета. Серия 4, История. Регионоведение. Международные отношения. -2021. - Т. 26, № 3. - С. 249-263. - DOI: https://doi.org/10.15688/jvolsu4.2021.3.22 
Введение. Положение латинос и особенно чиканос (это мексиканцы или потомки мексиканцев, проживающих в США) значительно отличается от положения афроамериканцев, не говоря уже о положении белого населения. В русском языке, как и в английском, термин «латинос» не является неполиткорректным, и поэтому используются оба термина «латинос» и «латиноамериканцы». Достаточно упомянуть используемую в настоящей статье англоязычную монографию [6], а также многочисленное использование термина латинос в статьях базы РИНЦ e-library в качестве ключевого слова.

В прокатившихся в прошлом году по всей стране выступлениях чернокожего населения в защиту своих гражданских прав в связи с убийством 46-летнего афроамериканца Джорджа Флойда 25 мая 2020 г. полицейским при его аресте Дереком Шовиным в Миннеаполисе не прозвучали выступления латинос за свои права, хотя их дискриминация намного значительнее, чем афроамериканцев. Права афроамериканцев после длительной борьбы были формально подтверждены принятыми законами в США во второй половине XX века. Права латинос, значительная часть которых не являются гражданами этой страны, не защищены законом, и на них, кроме законов, регулирующих миграцию, распространяются также действия указов президента. По этим указам строятся пограничные стены с Мексикой, недокументированные мигранты арестовываются и целыми семьями ждут своей участи в местах заключения, родившиеся в США дети и считающиеся гражданами США отделяются от своих родителей и разлучаются с ними. Все эти и другие подобные действия правительства США указывают на правовую и политическую сегрегацию латиноамериканцев в стремлении, как выразился Д. Трамп, к «освобождению» (liberation) американских городов от латинос и «возвращению Америки к политике "законности и правопорядка" (времен. - И. С.) никсонианства» [3, p. 1].

Прошедшим итогом четырехлетнего пребывания Д. Трампа в качестве президента США можно констатировать, что положение латинос только ухудшилось, а их «расовое неравенство и расовые социальные различия» (racial disparity and inequality) усилились
$[3$, p. 2]. Это утверждение целиком подтверждается нижеприведенным обзором публикаций американских авторов за 2018-2020 годы.

Методы. Для исследования указанных в обзоре публикаций использовался научный принцип объективности, который позволил оценить степень субъективной информации, содержащейся в обзоре использованных публикаций, порой отражающих разные политические предпочтения авторов и иногда искажающих реальное положение дел. Онтологический (субстанциональный) подход позволил уточнить изменения как в составе самих акторов, так и их действия в конфликтном процессе трансформационной политики Белого дома, который был представлен в новых американских исследованиях. Использование институционального метода дало возможность определить взгляды американских исследователей на изменение функций и деятельности различных ведомств американского правительства при решении иммиграционных вопросов и положения латиноамериканских граждан и не граждан в США во время президентства Д. Трампа.

Анализ. По данным Бюро переписи населения США, по состоянию на 2017 г. испаноязычное население в США составляло около $18 \%$ от общей численности населения страны, но их неравное положение по сравнению с белым населением требует дополнительных исследований [18, p. 7].

Анализ положения латиноамериканцев в США необходимо начать с коллективной монографии «Депортация в Америках: истории выдворения и сопротивления», которая развенчивает устоявшийся миф об этом государстве как «страны иммигрантов», «страны белых, которая депортировала, а не приветствовала людей, не белых или не совсем белых» [10, p. 1]. Восемь авторов и два редактора в семи главах убедительно показывают различные механизмы выдворения «нежелательных иностранцев» разных рас, национальностей и политических взглядов с территории Соединенных Штатов на протяжении более ста лет (с 1890 до 2015 г.). Нас по теме исследования в большей степени заинтересовали: Введение, написанное Донной Р. Габачча, Глава 2, подготовленная Эллиотом Янгом, и Глава 6, представленная Наталией Молина. 
Д.Р. Габачча отмечает, что история депортации цветного населения, и в большей степени мексиканцев, включает эволюцию методов высылки от простой депортации «за пределы деревни» (village outward) до «вынужденного перемещения〉 (coerced movement) согласно законодательству на федеральном и штатном уровне Соединенных Штатов [10, p. 2]. Причем, отмечает автор, подобный механизм нациостроительства был свойственен не только США, но и Мексике, и Канаде, хотя «различия, как и характер “создаваемых" наций, существенно различаются» $[10$, p. 2$]$.

Д.Р. Габачча отметила, что за годы президентства Б. Клинтона депортация в Мексику составила 12 млн чел., при Дж. Буше-мл. 10 млн чел., во время администрации Б. Обамы она сократилась до 5 млн чел., во многом потому, что количество незаконных переходов через южную границу резко сократилось после финансового кризиса 2008 г. [10, p. 5]. Следующий президент США Д. Трамп обвинил Б. Обаму в неспособности контролировать границу страны с Мексикой и в слишком мягком отношении со стороны правительства к нелегальным иммигрантам «в части предоставления прав на работу и обучение "мечтателей” (Dreamers)» [10, p. 5]. (Следует пояснить, что «мечтатели» - это дети иммигрантов, которые были доставлены в Соединенные Штаты без документов своими родителями и тем самым были временно защищены законом от их депортации.)

По мнению автора, клеймение преступниками мексиканцев, пересекающих американскую границу без документов, в период президентства Д. Трампа в 2017 г. описывало две новые тенденции. С одной стороны, в это время увеличился поток мигрантов из стран Центральной Америки, по сравнению с мигрантами из Мексики, а с другой - беженцы из этих стран, задержанные пограничниками США, многие из которых были просителями политического убежища, вместе с детьми, томились в американских центрах содержания под стражей неопределенное время, «поскольку ни Мексика, ни Соединенные Штаты не проявляли большого интереса к предоставлению им убежища» $[10$, p. 6].

Как обеспокоенно указывает другой автор монографии, Эллиот Янг: «Зажигательная антииммигрантская риторика президента Трампа и запланированное строительство пограничной стены (между США и Мексикой. И. С.) могут привести к разрыву того, что было столетием сотрудничества по вопросам безопасности границ» $[10$, p. 63]. Но, ради справедливости, следует признать, что Мексика выполняет свои обязательства перед США по укреплению своих собственных южных пограничных сил, которые финансируются американцами в рамках Южного пограничного плана.

Кроме того, автор второй главы подчеркивает, что американская сторона часто нарушает свои и международные обязательства по приему беженцев из стран Центральной Америки, возлагая ответственность на Мексику за пропуск мигрантов, имеющих «законные ходатайства о предоставлении убежища» $[10$, p. 64]. («Свои обязательства» заключаются в том, что с начала 1990-х гг. американский Конгресс ежегодно выделяет денежные средства Мексике в качестве компенсации затрат, связанных с высылкой мигрантов из стран третьего мира, главным образом из стран Центральной Америки, тех, кто направляется в Соединенные Штаты через Мексику.)

Следующий автор, Наталия Молина, в своем исследовании подчеркивает, что несмотря на конституционные основания (14-я поправка Билля о правах) о том, что любой родившийся в Соединенных Штатах является американским гражданином, многие мексиканские дети не могут получить Свидетельства о своем рождении в силу того, что у их родителей, имеющих мексиканские консульские удостоверения личности, со временем истекли сроки, что стало формальным препятствием для их идентификации. (По мексиканским законам родители-иммигранты, живущие в США, не могут возобновить эти карты.) В результате эти отказы препятствовали родителям организовать крещение своих детей, зачислить их в детские сады, школы или в специальные образовательные службы. А через годы, повзрослев, эти дети не смогут получить паспорта и водительские права, карточки социального страхования и работу. С другой стороны, под угрозу попала способность родителей получить работу, медицинскую страховку, свободно пе- 
ремещаться без документов, подтверждающих их родительские права [10, p. 164].

По мнению Наталии Молина, борьба за свидетельства о рождении является продолжением модели, коренящейся в популистских дискурсах и культурных представлениях, которые продвигают образ беременных мексиканских матерей, въезжающих в Соединенные Штаты со стратегической целью, рожать за счет американских налогоплательщиков, «намеренно рожая в США с целью обеспечить себе американское гражданство» [10, p. 165].

Тем самым родившиеся в США дети являются «якорем» в дальнейшей жизненной гавани своих родителей. Поэтому не случайно в Америке появился и прижился дословно «якорный малыш» (anchor baby), или термин «ребенок-гарант». Хотя этот термин является оскорбительным по содержанию для гражданина США, он фактически отражает суть американской иммиграционной политики, которая является неэффективной, если мексиканцы представляют собой больше чем половину недокументированных мигрантов в Соединенных Штатах [10, p. 166].

Кроме того, Н. Молина отмечает, что термин «ребенок-гарант» не используется для других групп иммигрантов с похожей историей из не латиноамериканских стран, что «изображает мексиканских иммигрантов недостойными для проживания в США» [10, p. 166].

Особое место в нашем обзоре занимает монография Эдуардо Контрераса «Латиноамериканцы и либеральный город: политика и протест в Сан-Франциско» [6]. Автор задался вопросом, почему латиноамериканцы либерального города Сан-Франциско проявляют меньшую политическую активность на выборах различного уровня, чем белые и афроамериканцы, хотя чувствуют себя комфортнее, чем в других городах Америки. Его исследования показали, что этому способствует сложившаяся городская среда из многоликого цветного населения и низкий уровень безработицы. В Сан-Франциско в июле 2018 г. на местном уровне был установлен минимальный размер оплаты труда в 15 долл. США в час, что было значительно выше, чем в других городах Америки [6, p. 255]. Кроме того, им было выяснено, что партийная принадлежность латиноамериканцев на протяжении
XXI в. оставалась относительно неизменной либеральной. Та же политическая идентификация ожидается и на предстоящих выборах президента США 3 ноября 2020 года.

По мнению автора, несмотря на многочисленные исторические примеры проявления протеста латиноамериканцами в XX в., в последнее время эти граждане Сан-Франциско в большей степени заняты вопросами социального прогресса внутри своей среды, чем политической борьбой. Как считает Э. Контрерас, этому способствуют особенности латинской культуры (latinidad), которая создает «особые этнорасовые маркеры, такие как Latino/a (латиноамериканец/латиноамериканка в США), Latin@ (латинянин или кто-то латиноамериканского происхождения) и Latinx (гендерно-нейтральный неологизм, используется вместо Latino или Latina, чтобы обратиться к людям из Латинской Америки. Данный термин обозначает культурную или этническую идентичность в Соединенных Штатах. Суффикс $\langle-\mathrm{X}\rangle$ может заменяться на $\langle-\mathrm{o} /$-a $\rangle$ в окончании существительных и прилагательных, которые типичны для грамматического рода на испанском языке. Множественное число Latinxs) - жест в сторону гендерной инклюзивности и плавного развития» [6, p. 14].

Вряд ли с этим мнением можно полностью согласиться. Безусловно, латиноамериканская культура имеет богатое прошлое и настоящее, но работы других американских авторов, в том числе указанных и в нашем обзоре, убедительно доказывают, что меньшая политическая активность латиноамериканцев связана с большей сегрегацией этой группы населения в США, по сравнению с другими этнорасовыми группами и большой прослойкой проживающего недокументированного, а, следовательно, и бесправного населения.

Монография Мануэля Гонсалеса «Мексиканцы: история мексиканцев в Соединенных Штатах» [14] в 2019 г. вышла третьим изданием (первое - состоялось в 1999 г.). Этот капитальный труд, охватывающий период с 1500-х гг. до настоящего времени, уточнялся и дописывался дважды, через каждые 10 лет. Его строго академическая библиография включает более 900 наименований.

Главная миграционная проблема для США, по мнению М. Гонсалеса, в период пре- 
зидентства Д. Трампа заключается в массовом прибытии иммигрантов из стран Центральной Америки через американо-мексиканскую границу. Это, по сути, вынужденное бегство от тотального насилия организованной преступности и невозможности достойного существования большинства людей в этих странах [14, p. 377]. Для США иммиграционная проблема стала комплексной, и включает в себя множество других проблем, требующих своего решения.

Первая из них - обратная депортация. Более $80 \%$ ходатайств, поданных беженцами из стран Центральной Америки, были отвергнуты миграционной службой США. Задержанные мигранты, в ожидании решения в течение нескольких месяцев, томились в тюрьмах, после чего были отправлены на свою родину. Как пишет автор Шанталь Да Сильва в журнале «Ньюсуик», Иммиграционно-таможенное управление США использовало авиакомпании - «Объединенные авиалинии», «Американские авиалинии» и «Дельта» для осуществления более 1200 рейсов в страны Центральной Америки для депортации беженцев в 2019 году. Кроме того, этим управлением использовались коммерческие авиакомпании для выполнения дополнительных чартерных рейсов по депортации [7]. При этом Сара Нельсон, президент Ассоциации стюардесс-CWA, которая представляет 50 тыс. стюардесс 20-ти авиакомпаний, сообщила журналу, что стюардессы не подписывались под тем, чтобы помогать в выполнении американской иммиграционной политики, «разрывающей семьи и разрушающей все (иммигрантские. - И. С.) сообщества» [8, p. 70-71].

Вторая проблема - это пересечение границы «несопровождаемыми» (unaccompanied) детьми, которые хотят воссоединиться со своими родителями, живущими в США. В 2016 г. около шестидесяти тысяч несопровождаемых детей были задержаны на американо-мексиканской границе Таможенно-пограничной службой США, большинство из них были дети из стран Центральной Америки. «Практически все они были перевезены койотами, которые взимали (с посредников. - И. С.) около семисот пятидесяти долл. США с каждого человека» [14, p. 378].
Третья проблема заключается в составе населения штатов «Солнечного пояса» [В литературе можно встретить название штатов «Солнечного пояса», как штаты южного края или Гранд Каньона (States of the Southern Rim)]. В США латиноамериканское население удваивается каждые 12-14 лет как за счет притока иммигрантов, так и высокой рождаемости в их среде. Население латиноамериканцев (с учетом нелегалов) в штате Калифорния составляет почти 45 \% от общей численности штата, в штате Техас $37 \%$. В ряде городов (Майами, Лос-Анджелесе, Сан-Антонио, Хьюстоне) латиноамериканцы составляют уже относительное большинство населения, и их доля повсеместно быстро увеличивается.

Четвертая проблема состоит в том, что латиноамериканские иммигранты растекаются по большинству штатов с преимущественно белым населением. По данным Исследовательского центра Пью (Pew Research Center) [19], мексиканцы стали самой многочисленной иммигрантской группой в тридцати трех штатах США в 2013 г., вызывая всплеск нативистских чувств у старожилов как по причине иных общекультурных традиций и ценностей (59 \% мексиканских иммигрантов не имеют завершенного школьного образования, $45 \%$ мексиканок в возрасте от 15 до 44 лет являются матерями-одиночками, $27 \%$ мексиканцев живут за чертой бедности, $33 \%$ не имеют медицинской страховки, а 57 \% вообще какого-либо страхования), так и незнания принятого языка общения (лишь $66 \%$ из них владеют английским разговорным языком).

Пятая, гуманитарная проблема, заключается в том, что увеличение препятствий возможного пересечения американо-мексиканской границы толкает людей на переход по пустынным территориям. Последствиями такого перехода являются обезвоживание, гипотермия, голодание и пропажа людей. М. Гонсалес приводит данные, что «с середины 2016 г. до середины 2017 г., таким образом, пропали без вести приблизительно 1200 человек» [14, p. 381].

Шестая проблема заключается в криминализации территорий по обе стороны американо-мексиканской границы, где известные 
картели (Juárez Cartel, Gulf Cartel, Sinaloa Cartel, Beltrán Leyva Cartel, Arellano-Félix Organization, Los Zetas, and La Familia Michoacana) ${ }^{2}$, объединившие торговцев наркотиками, койотов и контрабандистов, терроризируют пограничное население [14, p. 380].

М. Гонсалес обращает внимание на то, что в эру Д. Трампа перечисленные проблемы не только обострились, но к ним добавились новые, потому что либеральное отношение времен Б. Обамы к латиноамериканцам резко поменялось. Еще во время кампании по выборам президента Трамп признал свою собственную антипатию к мексиканским иммигрантам, «назвав их насильниками и наркодилерами, и обещал возвести стену, охватывающую всю американо-мексиканскую границу, чтобы не пустить этих “плохих парней” (bad hombres)» [14, p. 389].

Поэтому седьмой проблемой для латиноамериканцев стало решение президента Д. Трампа ограничить легальную иммиграцию. Миграционная реформа президента, по мнению М. Гонсалеса, не столько преследовала его цель «Сделать Америку снова великой» (make America great again), сколько «сделать Америку снова белой» (make America white again) [14, p. 397]. Д. Трамп не раз упоминал о необходимости вернуться к «историческим нормам» (historical norms) [14, p. 397] населения США. Для этого 2 августа 2017 г. президент обнародовал планы реформирования Закона об американской иммиграции для полной занятости (Reforming American Immigration for Strong Employment - RAISE), положения которого предполагали сокращение выдачи грин-карт ежегодно на 50 \%, отмену положения о воссоединении семей, которое содержалось в историческом Законе об иммиграции 1965 г., требования иметь определенные навыки и образование, а также способности говорить по-английски [14, p. 396]. Как продолжает М. Гонсалес: «Не может быть никаких сомнений в том, что эти меры были направлены, прежде всего, на мексиканцев и других латиноамериканских иммигрантов» [14, p. 396].

Восьмой проблемой для латиноамериканцев стало решение Д. Трампа продолжить строительство пограничной стены, начатое еще Дж. Бушем-мл. В середине февраля
2019 г., обращаясь к собравшимся в г. ЭльПасо, он сказал, что благодаря крепкой стене на границе в Эль-Пасо, Техас - это один из самых безопасных городов Америки сегодня [3]. По мнению автора исследования, «стена всегда была джокером в рукаве Трампа» в его популистской политике «по запрету въезда мусульман, высылке “плохих парней” и восстановления “"законности и правопорядка"» [3].

Между тем, как показывает история строительства пограничных стен, они не являются полным препятствием для проникновения на другую территорию [2]. Возникновение любых новых сложностей для перехода американо-мексиканской границы толкает мексиканцев и других латиноамериканцев на обращение к представителям организованной преступности, которые связаны с коррумпированными чиновниками по обе стороны границы, создавшими в эпоху Д. Трампа невиданно успешный и процветающий бизнес. Даже задержание на территории США становится частью этого бизнеса, где «из-за серьезных отставаний в принятии судебного решения по депортации такое задержание может продолжаться многие месяцы или даже годы» [15, p. 1855].

Выводы из исследования Кэтрин И. Ким, профессора права Бруклинской юридической школы, и Эми Семет, лектора количественных исследований в области социологии и политологии Колумбийского университета, состоят в том, что имеющиеся подходы в задержании не граждан и рассмотрение их дел должны быть изменены: необходимо выработать более строгие руководящие принципы в отношении факторов, которые следует учитывать при определении того, следует ли задерживать или освобождать не гражданина. «Единообразие не должно склоняться к длительному по времени содержанию под стражей» $[15$, p. 1900].

В более широком контексте о значении строительства различных стен в межкультурной коммуникации президентом Д. Трампом говорится в монографии Колина Дюка «Эпоха железа: о консервативном национализме» [11]. В ней автор утверждает, что президент США строит из Америки «крепость из различного вида серии стен - тарифных стен против иностранного экспорта, стен безопас- 
ности против мусульманских террористов, буквальных стен против латиноамериканских иммигрантов» $[11$, p. 3$]$.

Похожий вывод делает Назли Авдан (Nazli Avdan) в своем исследовании «Визы и стены: пограничная безопасность в эпоху терроризма». Он пишет, что границы продолжают иметь значение, но они берут на себя «роль щита против межнациональных угроз, а не традиционных, военных угроз» [2, p. 17]. Другими словами, для США латиноамериканская иммиграция представляет национальную угрозу в политическом, экономическом и культурном значениях.

Девятой проблемой стало решение президента Д. Трампа использовать IT-технологии, разрабатываемые в Силиконовой долине, для поиска, сбора, хранения и обработки информации о недокументированных мигрантах. Для этого Иммиграционная и таможенная полиция США (Immigration and Customs Enforcement - ICE) заключила коммерческий договор на 49 млн долл. США с фирмой Палантир (Palantir), основателем которой является Питер Тил (Peter Thiel), сроком до 2020 г. [Питер Тил, миллиардер с состоянием 2,5 млрд долл. США на конец 2018 г., соучредитель Палатир Технолоджис (Palantir Technologies), занимал должность советника президента Д. Трампа в конце 2016 - начале 2017 г.]. В результате взаимодействия с IT-компаниями сотрудники ICE устраивают массовые облавы латиноамериканцев на рабочих местах. Так, 7 августа 2019 г. они арестовали 680 работающих мужчин и женщин на птицефабриках в штате Миссисипи. Это были недокументированные рабочие, главным образом родом из Мексики и Центральной Америки, подлежащие депортации и в некоторых случаях федеральному судебному преследованию [9, p. 37]. Среди них были латинос, которые уже прожили в США более двух десятилетий, имеющие не только детей, но и внуков - граждан США. На их лодыжки были надеты тюремные браслеты, и они были отпущены по домам для последующего разбирательства [9, р. 37].

Разработанная фирмой Палантир программа «tipline» является не только информационной базой ICE, но также мощной поисковой системой Управления следственными делами, которая «агрегирует информацию сра- зу из сотен баз данных, способствуя сотрудникам проводить расследования» [9, р. 37]. Важно также сказать о том, что «Палантир» по требованию Министерства труда США в судебном порядке была оштрафована на 1,7 млн долл. США за дискриминационное отношение к латинос при найме на работу [16].

Десятой проблемой для латиноамериканцев, как живущих в США, так и за ее пределами, стали объективные ограничения, связанные с кризисом коронавируса. Запрет на путешествия, объявленный американским президентом Д. Трампом 11 марта 2020 г., ограничил перемещения через американо-мексиканскую границу не только для туристических и деловых поездок, но также и для запланированных миграционной службой поездок для воссоединения семей.

Далее 18 марта 2020 г. президент Д. Трамп ограничил права просителей убежища на американской южной границе под предлогом ограничения распространения коронавируса. Тем самым США вынудили 60 тыс. латиноамериканцев ожидать результаты судебных слушаний по их запросу об иммиграции в Мексике неопределенное время. Причем «Трамп жаловался, что его чиновники неспособны к выполнению его желания “закрыть границу" полностью» [23, p. 7].

Американские исследователи и эксперты считают, что пандемия коронавируса играет на руку националистам, которые выступают за усиление иммиграционного контроля и протекционизма [17, p. 23]. Пандемия в условиях предстоящих в США президентских выборов у электората повысила запрос на сильное правительство, способное поддержать национальную безопасность, даже в ущерб некоторым ограничениям в правах и свободах, а также в необходимых социальных потребностях.

Следующая коллективная монография «Сепараторные границы и лишение свободы в тюремных штатах, иммиграционные задержания и активное сопротивление» [4] написана коллективом, состоящим из четырнадцати ученых университетов США, Канады и Австралии, и опубликована в издательстве университета Северная Каролина в 2019 году. В ней отражены история и современное состояние положения цветного населения, про- 
живавших и проживающих в южных, юго-западных и западных штатах США, так называемого «Солнечного пояса». Авторы на большом историческом материале указывают на правовую и политическую сегрегацию латиноамериканцев (и прежде всего мексиканцев), которая была и остается значительной.

Редактор монографии Р. Чейз в своем обращении к читателю сразу же объясняет необходимость выхода в свет подобного исследования, указывая на то, что избрание президентом США Дональда Дж. Трампа способствовало соединению и переплетению двух отдельных сфер американского права - уголовного производства и иммиграции. Выступая перед офицерами Иммиграционной и таможенной полиции США (Immigration and Customs Enforcement - ICE) после вступления в должность в январе 2017 г., президент пообещал увеличить численность сотрудников этого ведомства почти втрое, с 6 тыс. до 16 тыс. чел., чтобы «“приручить” (tame) западную границу и освободить американские города от "недокументированных иммигрантов” через массовое лишение свободы» [4, р. 1].

Включенные в монографию работы авторов исследуют тюремные режимы различных штатов американского Юга и Запада для цветных, начало которых исходит от расового притеснения колониального периода в пограничных регионах и вдоль западных границ, с использованием дополнительных южных методов лишения свободы рабовладельческого времени [4, p. 2].

Использование образного термина «тюремные штаты» (carceral states) связано, по мысли редактора, с тем, что перед авторами монографии стояли задачи, во-первых, исследовать, географические различия, региональные истории, отдельные тюремные методы, государственные акты, найти ответы на вопрос о построении сложной системы тюрем и действующих акторов на местном, штатном, региональном, национальном и даже межнациональном уровнях [4, р. 4], а во-вторых, показать, что федеральная власть в условиях построения широкой федерации самоустранилась от правоприменительной практики, передав ее в юрисдикцию штатов [4, p. 5]. В то же время в каждом эссе прослеживаются вопросы научного исследования о том, как в Cо- единенных Штатах появился «самый высокий в мире уровень тюремного заключения и система, которая в основном заключает под стражу этнические меньшинства» [4, p. 5].

Редактор указывает на то, что в 2016 г. в США было 2,3 млн заключенных. При численности населения $5 \%$ от мировой численности, Соединенные Штаты имеют 25 \% заключенных от числа всех заключенных в мире, которые содержатся в 102 федеральных тюрьмах, в 1719 тюрьмах штатов, в 2259 исправительных учреждениях для малолетних преступников, в 3283 муниципальных и 79 специальных тюрьмах для индейцев. К этому числу следует добавить 200 пунктов для временного содержания иммигрантов [4, р. 6].

Если до событий 9/11, за тридцать лет после бунта в тюрьме Аттики (Аттика - это тюрьма штата Нью-Йорк категории максимальной/супермаксимальной безопасности, расположена в г. Аттика, находится в ведении Департамента исправительных служб штата Нью-Йорк. После завершения строительства в 1930-х гг. там содержались многие опасные преступники того времени. В столовой и производственных помещениях тюрьмы установлена система, распыляющая слезоточивый газ с целью подавления конфликтов) в 1971 г. число заключенных латиноамериканцев увеличилось в 10 раз, то с созданием Министерства внутренней безопасности после принятия Патриотического Акта 2001 г. «иммиграционное право полностью перешло из области внешней политики и стало вопросом уголовного права и агрессивного принуждения» [4, p. 8]. Следует отметить, что этот авторский вывод полностью подтверждается авторами других публикаций.

В американскую статистику роста числа преступлений среди латиноамериканцев включаются общие цифры проживающих латинос на территории США незаконно, без надлежащих документов. Учитывая, что эта категория людей утроилась с 3,5 млн в 1990 г. до 11,2 млн в 2013 г., можно согласиться с политическим географом Майком Дэвисом (Mike Davis), что американская «граница больше, чем просто национальная линия образов, отделяющая две страны, ...она следует за рабочими латиноамериканцами везде, где они живут и независимо от того, сколько 
времени они прожили в Соединенных Штатах» [8, p. 70-71].

Со времен президентства Дж. Буша-мл. проблема проживания в США латинос выросла в национальную проблему. Действительно, по этим вопросам имеется многочисленная библиография исторических и политологических работ американских авторов за последние двадцать лет.

Латиноамериканцы в силу их значительного проживания без документов подвергаются «криммиграции» (crimmigration) или криминальной миграции (криминальная миграция это перемещение людей через границы или иные территории в целях совершения преступлений, как правило, в сфере экономической деятельности, а также террористических актов, что объективно представляет повышенную опасность для общества и существенно влияет на состояние криминогенной обстановки). Так, в 2013 г. из общего числа иммигрантов, высланных Иммиграционной и таможенной полицией США, 438000 чел. были латиноамериканцы, которые составили $97 \%$ от числа всех депортированных [4, p. 9].

Во второй части этой монографии исследуется введение в научный оборот термина «Солнечный пояс», состоящего из американских штатов, которые после Второй мировой войны заметно возвысились в области экономики за счет привлечения сезонных латиноамериканских рабочих. «Южные агропредприятия создали более сложную мозаику новых политических союзов, этнических разделений и культурных практик» [4, p. 14].

В эссе «“Они все, что у нее есть”: бывшие заключенные женщины и право голоса, в 1890-1945 гг.» профессора истории университета Среднего Теннесси, Пиппы Холлоуэй (Pippa Holloway), рассматривается борьба американских женщин «Солнечного пояса» за предоставление им полных гражданских прав согласно XIX поправки к Конституции США, благодаря которой в 1920 г. вводилось активное избирательное право для женщин (XIV поправка, ратифицированная 1868 г., давала право на гражданство США всем родившимся на территории страны, но не давала избирательных прав женщинам и преступникам).

Автор эссе указывает, что любое осуждение женщины по суду лишало ее гражданс- ких избирательных прав на всю оставшуюся жизнь. «Между 1874 и 1882 гг. все южные штаты, кроме штата Техас, внесли поправки в свои конституции и пересмотрели свои законы, чтобы лишить гражданских прав (женщин. - И. С.) за мелкое воровство» [4, p. 190].

Южные штаты США поддержали юридическую традицию позора (legal tradition of infamy), увековечивая идею, что осужденные «на позор» должны иметь полное или частичное лишение гражданских прав. Такие осужденные не могли служить в качестве поверенных, в Мэриленде - страховыми брокерами, в Аризоне, Техасе и восьми других штатах не могли получить медицинские лицензии, в Миссури - лицензии на продажу спиртного [4, p. 194]. Учитывая, что перечисленные профессии в большей мере затрагивали мужчин, ограничение в гражданских правах касалось и женщин.

В эссе «Что случилось с южными "скованными цепью бригадами"? Изобретение дорожной тюрьмы в "Солнечном поясе" Флориды» адъюнкт-профессора из университета Ноттингема Вивьена Миллера исследуются изменения, которые произошли в дорожных тюрьмах штата Флориды после известного пожара в тюрьме Джей-роуд в 1967 г., когда погибли 38 заключенных в деревянной тюрьме. Это событие в период борьбы за гражданские права вызвало волну протестов на территории США и способствовало модернизации тюремной системы в штатах «Солнечного пояса»: дорожные департаменты штатов (State Road Department - SRD), управлявших «скованными цепью бригадами» из заключенных на строительстве дорог, были заменены Общественными исправительными центрами (Community Correctional Centers - CCCs). Позже всех замена дорожных тюрем произошла в штате Флорида: последняя тюрьма была ликвидирована лишь в апреле 2017 г. [4, p. 230].

Автор указывает, что модернизация системы дорожных тюрем проводилась в течение тридцати лет и включала в себя процесс десегрегации (тюрьмы пополнялись белыми и цветными заключенными), заключенные проходили профессиональное обучение и могли использовать полученные знания для выполнения работы более эффективно, некоторые тюрьмы для преступников низкого уров- 
ня были преобразованы в лагеря лесоводства в штате Калифорния, другие переданы под Управление национальными парками и лесами во Флориде.

Редактор монографии справедливо считает, что анализ В. Миллера показывает, что «дорожные тюрьмы "остаются частью уголовного портфеля штатов в конце XX - начале XXI в.”, где переход от Нового юга к “Солнечному поясу" определялся скорее "переработкой и переобновлением, а не драматической реформой и реструктуризацией”» [4, p. 32].

В XX в., как указывает Хизер Маккарти, процесс создания внутренних тюремных сообществ (названных бригадами) по их принадлежности к определенному виду криминальной культуры или направлений криминальной деятельности оставшихся на свободе преступников, непрерываемой с ними связи и конкуренции между «бригадами» проходил сначала в среде белых преступников, затем афроамериканских. В XXI в. первенство от них перешло к бригадам, состоящим из латиноамериканцев [«Мексиканская мафия», также известная как «Ла Эмэ» (Mexican Mafia or La Eme), «Нуэстра Фамилия» (Nuestra Familia (NF) or La Familia)].

К тому же администрация тюрем, например, Калифорнии, поддерживала расовый сепаратизм и межрасовое насилие, создавая напряженные отношения в тюремной системе. Это происходило по понятным причинам: афроамериканские бригады, кроме всего прочего, участвовали в политическом движении за гражданские права, в то время как мексиканские бригады «торговали в тюрьме героином и занимались ростовщичеством» [4, p. 257]. Бригада «Нуэстра Фамилия» стала самой влиятельной преступной группировкой, использовала революционную риторику, политику «кровь за кровь», структуру военной организации: бригадой командовал генерал Ностра, через капитанов и лейтенантов привлекали в рядовые члены - soldados, которые спонсировали бригаду входной платой и давали клятву верности [4, p. 259].

Хизер Маккарти утверждает, что в период президентства Р. Рейгана из-за потери контроля над тюремными бригадами в США были построены тюрьмы строгого режима (supermax prisons), но они не способствовали решению проблемы: «Сегодня бригады продолжают управлять большой частью социального мира заключенных, и усилия тюремных служащих подорвать это управление терпят неудачу» [4, p. 271]. Поэтому автор делает вывод, что в регионе «Солнечного пояса» создана новая система применения закона Джима Кроу в замаскированной криминализированной форме. Во-первых, в «штатах южной оправы» находятся 78 из 105 национальных тюрем строгого режима, с более чем двумя тысячами заключенных, во-вторых, эти тюрьмы содержат в основном камеры смертников и в них более половины заключенных США были приговорены к смерти [4, p. 280]. В-третьих, в этих штатах используют отличную от национальной систему общественного блага большинство общественных работ выполняется заключенными, а выборы в органы власти традиционно проходят под лозунгом: кто из кандидатов пообещает не увеличение дохода от собираемых налогов, а более дешевые контракты на выполнение общественных работ за счет бесплатной тюремной рабочей силы. В-четвертых, начиная с 1960-х гг. эволюция частного предпринимательства в «Солнечном поясе» шла от предоставления услуг в небольших «социальных гостиницах» для условно освобожденных преступников до полного управления частными тюрьмами в XXI веке. По словам В. Янссена: «Переход от заботливого ухода к содержанию под стражей и от общественной помощи к наказанию включал в себя экономические преобразования и сложную сеть решений на уровнях регионального управления, тюремной администрации и корпорации, которые вместе включались в политэкономию “Солнечного пояса"» [4, p. 282].

Другой авторский вывод заключается в том, что создание тюремного промышленного комплекса в регионе «Солнечного пояса» было обеспечено двумя условиями: поддержкой его создания федеральным правительством и близким расположением государственной границы. Поэтому уже к 2004 г. в «Солнечном поясе» было три четверти частных тюрем США [4, р. 283]. В то же время В. Янссен не берется судить о том, как будет развиваться частная сеть тюрем «Солнечного пояса» в жестких условиях, предъявляемых новым президентом США Д. Трампом к су- 
ществующему потоку недокументированных иммигрантов из Мексики и стран Центральной Америки.

Рассуждая далее, автор указывает на странность, что ни у одного законодателя подобная внутритюремная модернизация не вызвала вопросов в ее необходимости или желательности, и ни один судья не подверг сомнению отправку заключенных в такие тюрьмы, в которых «крайняя форма наказания» (extreme form of punishment) превышала установленную приговором [4, p. 331].

В свете перечисленных условий соблюдения прав латинос в США не может не быть рассмотренной коллективная монография «Кризис прав человека в Мексике» [18] под редакцией Алехандро Анайя-Муньоса, профессора-исследователя кафедры социальных, политических и юридических исследований Западного института технологий и высшего образования (Instituto Tecnológico y de Estudios Superiores de Occidente - ITESO), и Барбары Фрэй, доктора юридических наук, старшего лектора института глобальных исследований в университете Миннесота. В ней авторы исследуют причины массового исхода мексиканцев и латиноамериканцев из стран региона в США в XXI в. и делают вывод, что эти люди становятся вынужденными иммигрантами в силу объективных причин - невозможности существования в своих странах. При этом действия администрации президента Д. Трампа в вопросе латиноамериканской иммиграции выглядят антигуманными и антипереселенческими (antirefugee).

Президент США не хочет признавать условия, которые вызывают рост нелегальной иммиграции в более чем половине штатов его страны: это кризис прав человека в Мексике, связанный в первую очередь с тремя категориями насилия - внесудебными убийствами, исчезновениями и пытками мексиканцев.

Внесудебные убийства начались во время президентства Винсента Фокса (20002006 гг.) как «демонстрация силы» (shows of force) (армией, флотом и федеральной полицией) и «кровавого ответа» (bloody response) правительства (наркокартелям и организованной преступности) [1, p. 2].

Следующий президент Фелипе Кальдерон (2006-2012 гг.) начал свою так называе- мую «войну с наркотиками» (war on drugs), в которой главным образом были задействованы правительственные войска. Развернувшиеся многочисленные битвы увеличили в несколько раз насилие в стране, что, безусловно, сказалось на населении, и люди были вынуждены бежать (в том числе и нелегально) в США, чтобы иметь для себя более безопасное место для проживания.

Несмотря на то что президент Энрике Пенья Ньето (2012-2018 гг.) оставил подстрекательскую риторику «войны с наркотиками», федеральные силы не только продолжали эту войну, но и усилили ее эффективность. Если в 2007 г. на каждого раненого «федерала» приходилось 6,8 чел. убитых преступников, то в 2013 г. соответственно - 19,4 чел. [1, p. 11-12]. Мексиканский президент Лопес Обрадор, принявший присягу 1 ноября 2018 г., немного сделал, чтобы восстановить права человека в Мексике. Он избежал поединков с Д. Трампом по вопросам иммиграционной политики, и у них обоих сложились «удивительно теплые отношения, несмотря на принадлежность к различным концам политического спектра» [21, p. С7]. Оба президента говорят об искренней дружбе между США и Мексикой, которая, кажется, проявляется в их стремлении следовать националистической повестке дня [20, p. 49].

Отметим, что действия правительства США и президента Д. Трампа, направленные на ограничение «американского убежища» для латиноамериканцев, привели к тому, что «Совет по иммиграционным апелляциям (Board of Immigration Appeals - BIA) и федеральные суды стали узко толковать право на его получение, когда заявители ходатайствуют о защите от возмездия со стороны преступных группировок. Суды отказываются признавать "политическое действие" или принадлежность к “конкретной социальной группе” (к преступным группировкам. - И. С.), когда истцы, например, утверждают, что сопротивление вербовке или действиям сексуального характера (членами банды) представляет собой “политическое действие" или что преступные группировки представляют собой “конкретную социальную группу”» [1, p. 172].

Конечно, возникает вопрос о том, как гражданское общество США реагирует на 
трансформационные изменения в иммиграционной политике Д. Трампа? В целом борьба против насильственных мер правительства в вопросе латиноамериканской иммиграции носит спокойный, уравновешенный и ненасильственный характер. В качестве активистов выступают: «Католическое движение социальной справедливости» (Catholic social justice movement); Католическая коалиция лидерства (Catholic Leadership Coalition); Католическая коалиция федерального округа Колумбия (DC Catholic Coalition); Сестры милосердия Америк (Sisters of Mercy of the Americas); американские отделения Международного католического христианского движения «За мир», расположенные в Штатах (Pax Christi) [22, p. 1]. Кроме того, ширится движение за декриминализацию американо-мексиканской границы, которая может быть достигнута, с одной стороны, «политикой нулевой терпимости администрации» (administration's zero-tolerance policy), а с другой - необходимой отменой в федеральном уголовном праве раздела 1325 «о незаконном въезде» (illegal entry) и раздела 1326 «о незаконном возвращении» (illegal reentry) [12, p. 1967A].

Необходимо также учитывать, что если на выборах президента США в 2016 г. участвовали 12,7 млн латиноамериканских избирателей, то в 2020 г. их участие составит уже 15 млн чел., и, таким образом, латиноамериканское голосование становится "Джокером» (wild card) или непредсказуемым фактором на президентских выборах 2020 г. [5, p. 41].

Результаты. Проведенный обзор проблематики политических трансформаций американской политики в отношении латинос во время президентства Д. Трампа по публикациям американских авторов за 2018-2020 гг. позволил получить новые общие и частные результаты для отечественной историографии. Общие результаты заключаются в том, что за последние годы в американском научноэкспертном сообществе сформировалось устойчивое мнение, что несмотря на трансформацию внутренней и внешней политики каждым последующим правительством США в XXI в. положение латиноамериканцев существенно не меняется. «Проблема латинос» остается и передается для ее решения следующему правительству. Другой особен- ностью всех представленных работ является выражение беспокойства по вопросу усугубления нативистского положения латиноамериканских граждан и не граждан в США. Третье положение отражает мнение авторов публикаций о том, что подобная политика ведет к «размыванию» американских ценностей как страны иммигрантов. Четвертое, и в этом американские авторы едины: проводимая администрацией президента Д. Трампа этническая и иммиграционная политика способствует не единению, а большему разобщению американского общества [13, p. 1-2].

Из частных результатов можно выделить указание американских авторов на то, что наибольшее нарушение прав и свобод латиноамериканцев происходит в штатах так называемого «Солнечного пояса» и западных штатов США; нарушения же в правах латиноамериканских беженцев чаще всего наблюдаются на южной американо-мексиканской границе. Часть авторов считает, что проблема иммиграции латиноамериканцев в США не может решиться без совместных действий американского и мексиканского правительств. В целом же при растущей критике положения латинос в США авторы исследований не предлагают кардинального решения этой проблемы.

\section{ПРИМЕЧАНИЯ}

${ }^{1}$ Исследование выполнено при финансовой поддержке РФФИ в рамках научного проекта № 20-014-00040.

The reported study was funded by RFBR, project number 20-014-00040.

2 Латиноамериканские криминальные организации, действующие на территории Мексики и стран Центральной Америки:

Juárez Cartel - картель Хуареса, также известный как «Организация Висенте Каррильо Фуэнтеса» - один из крупнейших мексиканских наркокартелей, базирующийся в городе Сьюдад-Хуарес (Чиуауа, Мексика), поставляет в США и Европу кокаин, марихуану и героин.

GulfCartel - картель Гольфо ('картель Мексиканского залива', Cártel del Golfo) - криминальная организация в Мексике, занимающаяся международной торговлей наркотиками и другими видами криминальной деятельности, располагается на территории мексиканского города Матаморос. 
Sinaloa Cartel - Тихоокеанский картель (исп. Sinaloa; Pacific Cartel) - самый крупный наркокартель Мексики. Известен также как Guzmán-Loera Organization. На долю картеля приходится до 60 \% всего наркотрафика в США. 31 октября 2011 г. в ходе масштабной спецоперации мексиканские вооруженные силы захватили 599 самолетов и вертолетов, связанных с картелем Синалоа. Это почти в пять раз больше отечественного флота Aeromexico, хотя, надо отметить, большая часть самолетов картеля Синалоа небольших размеров.

Beltrán Leyva Cartel - Бельтран Лейва - один из крупнейших наркокартелей в Мексике. Картель Бельтран Лейва ответственен за транзит и оптовую торговлю кокаином, производство и оптовую торговлю марихуаной и героином, управляет многочисленными транзитными коридорами торговли наркотиками и участвует в контрабанде людьми, отмывании денег, вымогательстве, похищении, убийствах и контрабанде оружия.

Arellano-Félix Organization - Тихуанский картель, или организация Арельяно-Феликса (Картель Арельяно-Феликса, CAF ) является мексиканским наркокартелем, основанным в Тихуане. В 2016 г. организация стала известна как Картель Тихуаны Нового Поколения (Cartel Tijuana Nueva Generación) и начала присоединяться к картелю Нового поколения Халиско вместе с организацией Бельтрана Лейва (BLO) для создания союза против картеля Синалоа.

Los Zetas - «Лос-Сетас» - криминальная организация Мексики, занимающаяся международной торговлей наркотиками и другими видами криминальной деятельности. Этот наркокартель укомплектован дезертирами из элитных частей мексиканской армии (спецназ GAFE (Grupo Aeromóvil de Fuerzas Especiales) и стрелковой парашютной бригады (BFP), связан с коррумпированными чиновниками из федерального правительства и местных администраций и полицейскими офицерами, кроме этого, в картель вступили бывшие военнослужащие Гватемалы.

La Familia Michoacana - Ла Фамилиа Мичоакана (La Familia) - один из основных мексиканских наркокартелей, действовавший в 20062011 годах. Штаб-квартира картеля находилась в юго-западном штате Мичоакан. Ранее картель действовал в союзе с Лос-Сетас как часть картеля Гольфо. С 2006 г. Ла Фамилиа стал независимой преступной организацией. Лидер картеля и один из его основателей Насарио Морено Гонсалес, известный как Эль Мас Локо (исп.: «самый сумасшедший»). По словам генерального прокурора Мексики Эдуардо Медина Мора, Ла Фамилиа - «самая жестокая преступная организация в Мексике».

\section{REFERENCES}

1. Anaya-Muñoz A., Frey B. Mexico's Human Rights Crisis. Philadelphia, University of Pennsylvania Press, 2019. 326 p.

2. Avdan N. Visas and Walls: Border Security in the Age of Terrorism. Philadelphia, University of Pennsylvania Press, 2019. 244 p.

3. Burleigh N. How Donald Trump Played the (White) Race Card and Reshaped the Democratic Party; the President Changed the Way We Talk About Race. Now 2020 Is a Referendum on Diversity. Newsweek, 2019, vol. 172, iss. 8, March 15, p. 68. URL: https:// www.newsweek.com/2019/03/15/trump-racedemocrats-identity-politics-2020-1352568.html (accessed 28 September 2020).

4. Chase R.T., ed. Caging Borders and Carceral States: Incarcerations, Immigration Detentions, and Resistance. Chapel Hill, University of North Carolina Press, 2019. $427 \mathrm{p}$.

5. Castallanos N., Heltzel P.G., Valentin E. The Willdcard: Evangelicos in the 2020 Election. Cross Currents, 2020, vol. 70, iss. 1, p. 41.

6. Contreras E. Latinos and the Liberal City: Politics and Protest in San Francisco. Philadelphia, University of Pennsylvania Press, 2019. 316 p.

7. Da Silva Ch. United, Delta and American Airlines Used for More Than 1,000 Deportation Flights to Central America in 2019; United Airlines Facilitated 677 Discounted Deportation Flights from January 1, 2019 to January 16, 2020. Newsweek, 2020, vol. 174, iss. 4, February 14. URL: https://www.newsweek.com/ united-delta-american-airlines-deportation-flightscentral-america-1484940 (accessed 30 September 2020).

8. Davis M. Magical Urbanism: Latinos Reinvent the Big U.S. City. New York, Verso Press, 2001. 172 p.

9. Del Valle G. Deported by Silicon Valley. New Internationalist, 2020, iss. 523, p. 37.

10. Zimmer K., Salinas C., eds. Deportation in the Americas: Histories of Exclusion and Resistance. College Station, Texas A\&M University Press, 2018. 232 p.

11. Dueck C. Age of Iron: On Conservative Nationalism. New York, Oxford University Press, 2019. $228 \mathrm{p}$.

12. Eagly I.V. The Movement to Decriminalize Border Crossing. Boston College Law Review, 2020, vol. 61, iss. 6, January 1, p. 1967A.

13. Chase R.T., ed. Forget the Tweets, Read the Contract. Caging Borders and Carceral States: Incarcerations, Immigration Detentions, and Resistance. Chapel Hill, University of North Carolina Press, 2019. 440 p.

14. Gonzales M.G. Mexicanos: A History of Mexicans in the United States. Bloomington, IN, Indiana University Press, 2019. 475 p. 
15. Kim C.Y., Semet A. Presidential Ideology and Immigrant Detention. Duke Law Journal, 2020, vol. 69, iss. 8, pp. 1855-1903.

16. Kravets D. Palantir Settles US Charges that it Discriminated Against Asian Engineers. Ars Technica. Retrieved 26 April 2017. URL: https://arstechnica.com/ tech-policy/2017/04/palantir-settles-us-charges-itdiscriminated-against-asian-engineers/?comments $=1$ (accessed 28 September 2020).

17. Legrain Ph. Will the Coronavirus Kill Globalization? The Pandemic Is Legitimizing Nationalists and Turning Their Xenophobia into Policy. Foreign Policy, 2020, iss. 236, p. 23.

18. Mateos E. Latinos in America: USA Today Launches Hecho En USA, a Spanish-Language Series. Editor \& Publisher, 2020, vol. 153, iss. 3, p. 7.
19. Modern Immigration Wave Brings 59 Million to U.S., Driving Population Growth and Change Through 2065. PewResearch Center, Sept. 28, 2015. URL: http:// www.pewhispanic.org/2015/09/28/modern-immigrationwave-brings-59-million-to-u-s-driving-population-growthand-change-through-2065/ (accessed 28 September 2020).

20. Nau H.R. Course Correction. The National Interest, 2020, iss. 167, p. 49.

21. Riechmann D., Colvin J. Trump Forgoes Insults of Past, Calls Mexico Cherished Friend. Telegraph - Herald (Dubuque), 2020, July 9, p. C7.

22. Salvadore S. Immigration Activists Step Up in Battle Against Trump Policies. National Catholic Reporter, 2020, vol. 56, iss. 10, February 21, p. 1.

23. Trump Changes His Coronavirus Prognosis. The World Today, 2020, vol. 76, iss. 2, p. 7.

\section{Information About the Author}

Ilya A. Sokov, Doctor of Sciences (History), Professor, Department of International Relations, Political Science and Area Studies, Volgograd State University, Prosp. Universitetsky, 100, 400062 Volgograd, Russian Federation, sokov@volsu.ru, https://orcid.org/0000-0002-7146-7340

\section{Информация об авторе}

Илья Анатольевич Соков, доктор исторических наук, профессор кафедры международных отношений, политологии и регионоведения, Волгоградский государственный университет, просп. Университетский, 100, 400062 г. Волгоград, Российская Федерация, sokov@volsu.ru, https://orcid.org/0000-0002-7146-7340 